\title{
PERANAN TEKNOLOGI DALAM PENINGKATAN MUTU PENDIDIKAN PEMBELAJARAN BAHASA DI SMAN 1 KATINGAN HULU KABUPATEN KATINGAN
}

\author{
Ni Putu Eka Merliana*, Ni Nyoman Tantri, Evie, Winawati \\ Institut Agama Hindu Negeri Tampung Penyang Palangka Raya \\ *putuekamerliana@iahntp.ac.id
}

diterima 15 Juli 2019, direvisi 27 Agustus 2019, diterbitkan 31 Agustus 2019

\begin{abstract}
Technology becomes a thing that has an influence on the life needs of society as a whole, both to fulfill economic, social, cultural and educational needs. One of the things that is concerned by the government at this time is the progress of the quality of education which is the basis for educating the Indonesian people as a whole. The breakthrough made by the government to improve the quality of education is to implement a curriculum based learning system (K-13) in which students both at the elementary school level, junior high school and high school must be creative and innovative in implementing learning in the classroom. The application of this curriculum cannot be separated from the use of technology where teachers and students can develop dynamic and fun learning. One of the subjects offered in K-13 learning is language learning where these subjects become the foundation of students to carry out communication and interaction everyday. Therefore, the aim of the study is to know how to improve quality in language learning in SMAN-1 Katingan Hulu, Katingan Regency.
\end{abstract}

\section{Keywords: Education quality, Kurikulum 2013, Technology}

\section{PENDAHULUAN}

Perkembangan teknologi saat ini sangat berpengaruh terhadap kehidupan masyarakat secara umum, baik itu dibidang sosial, politik, hukum, pendidikan maupun budaya. Masyarakat dituntut untuk memahami dalam penggunaan teknologi sehingga teknologi menjadi suatu kebutuhan hidup yang dapat dirasakan oleh masyarakat baik itu didaerah maupun dikota seiring dengan perkembangan zaman. Hal ini yang mengakibatkan munculnya berbagai inovasi serta kreatifitas dalam penggunaan teknologi yang dapat membantu berbagai macam kegiatan salah satunya adalah kegiatan dibidang pendidikan. Pendidikan merupakan hal yang penting untuk memajukan kecerdasan bangsa Indonesia sehingga pemerintah saat ini lebih 
menggutamakan dalam memajukan mutu dibidang pendidikan. Proses pembelajaran dalam dunia pendidikan merupakan interaksi yang dilakukan antara peserta didik dengan tenaga pengajar dalam melakukan transfer ilmu dengan menggunakan media tertentu agar pengetahuan dapat diterima dengan baik oleh pendengarnya. Menurut (Sapto, 2009) pembelajaran pada hakikatnya merupakan proses komunikasi yang bertujuan untuk menyampiakan pesan/informasi yang dapat merangsang pikiran, perasaan dan perhatian para peserta didik. Seorang guru dapat memberikan kesempatan kepada para siswa untuk selalu aktif dalam melakukan proses belajar mengajar nantinya diharapkan dapat diterapkan dalam kehidupan sehari-hari Pembelajaran yang secara umum digunakan adalah pembelajaran satu arah dengan metode ceramah dimana seorang guru hanya menerangkan dan menjelaskan didepan kelas dengan menggunakan media papan tulis dan buku sebagai pedoman mengajar. (Sudarsana, 2017) menerangkan bahwa metode ceramah merupakan metode yang diterapkan oleh tenaga pengajar ke peserta didik dalam menyampaikan materi secara lisan didalam kelas. Penelitian yang dilakukan oleh (Muhson, 2010) menyatakan bahwa dalam pembelajaran dengan metode ceramah, para peserta didik hanya dapat menyerap 5\% dari materi yang telah disampaikan oleh guru, sedangkan $90 \%$ terjadi jika aktivitas belajar dilakukan dengan teman sebayanya.

Melihat hal tersebut, maka perlu adanya suatu inovasi yang dapat dikembangkan untuk meningkatkan mutu pendidikan dalam proses belajar mengajar. Pembelajaran aktif itu diinspirasi oleh beberapa penerapan pembelajaran yang aktif, inovatif, kreatif dan menyenangkan sehingga siswa dapat betah dan cepat menerima pelajaran yang diajarkan. Salah satu inovasi yang digunakan adalah dengan menggunakan media teknologi informasi yang menjadi media pembelajaran modern. Upaya yang dilakukan juga tidak bisa lepas dari campur tangan pihak sekolah, (Triyanto, Eko; Anitah, Sri; Suryani, 2013) menyatakan bahwa pemanfaatan media pembelajaran memberikan dampak positif dalam proses belajar mengajar sehingga membantu para peserta didik dalam memberikan materi pelajaran yang bersifat dinamis dan tidak monoton.

Secara umum teknologi informasi dan teknologi komunikasi memiliki makna yang berbeda. (Rogers, 1986) mengatakan bahwa teknologi informasi berarti peralatan perangkat keras, struktur organisasional dan nilai sosial dimana individu-individu dapat mengumpulkan, mengolah dan saling bertukar informasi dengan individu lain. Sementara teknologi komunikasi adalah semua hal yang mencakup sistem komunikasi seperti satelit siaran langsung, kabel interaktif dua arah, penyiaran bertenaga rendah, serta televisi (termasuk video disk dan video tape cassete). Komunikasi modern saat ini sudah dikombinasikan dengan teknologi dan komunikasi tersebut dalam bentuk ponsel seperti smartphone, android, teleconference dan bentuk alat komunikasi lainnya. Dengan kemajuan teknologi baik itu teknologi informasi dan teknologi komunikasi, peningkatan mutu dalam bidang pendidikan dapat didukung oleh hal tersebut. Salah satu peningkatan mutu yang penting dilakukan adalah dalam pembelajaran bahasa, karena kebanyakan pembelajaran bahasa mengalami kesulitan untuk mentransfer pengetahuan bahasa ke para peserta didik.

Peran teknologi yang membantu dalam meningkatkan mutu pendidikan untuk proses pembelajaran yang dapat menjadikan proses tersebut lebih menyenangkan. (Sapto, 2009) mengatakan bahwa perkembangan teknologi khususnya teknologi informasi dan komunikasi banyak menawarkan berbagai 
kemudahan-kemudahan dalam pembelajaran siswa yang memungkinkan terjadinya pergeseran orientasi pembelajaran dari proses penyajian berbagai pengetahuan menjadi proses bimbingan dalam melakukan eksplorasi individual terhadap ilmu pengetahuan. Teknik mengajar yang dilakukan oleh seorang guru dengan mempergunakan media teknologi informasi merupakan sistem pengajaran yang memanfaatkan perangkat keras dan perangkat lunak suatu komputer dalam sistem pembelajaran yang akan diberikan. Terdapat beberapa contoh yang dilakukan untuk meningkatkan mutu pendidikan dengan menggunakan teknologi informasi. (Marzal, 2014) menyampaikan bahwa teknologi informasi dapat membantu perubahan sistem pembelajaran siswa yang mengalami tuna rungu, yaitu dengan menggunakan alat bantu visual dalam pembelajaran. (Kwartolo, 2010) mengatakan bahwa pemanfaatan teknologi dalam pembelajaran bahasa inggris dapat membantu guru dalam melakukan interaksi pembelajaran siswa salah satunya adalah menggunakan teknologi komputer. Misalnya guru dapat mentransfer file/materi dari komputer yang ada di ruangan master kontrol, selain itu guru juga dapat melatih intonasi dan pengucapan bahasa inggris dengan menggunakan software DDL teacher dan DLL student. Pembelajaran yang bersifat dinamis tidak akan pernah menutup adanya perubahan dalam meningkatkan kualitas mutu pendidikan.

Salah satu pelajaran yang dapat meningkatkan keterampilan dan kemampuan siswa yaitu pelajaran bahasa karena bahasa menjadi alat yang digunakan untuk berkomunikasi dalam menyampaikan gagasan, ide, pendapat maupun informasi kepada orang lain sehingga pelajaran ini memerlukan praktek dan pemahaman siswa dalam penggunaan bahasa yang baik dan benar sesuai dengan ejaan yang telah disempurnakan (EYD). Pembelajaran bahasa dianggap penting karena berhubungan praktek komunikasi dengan menggunakan bahasa yang akan digunakan dalam kehidupan sehari-hari. (Fridani, Lara; Dhieni, 2014) menjelaskan bahasa adalah suatu simbol yang digunakan untuk berkomunikasi dengan orang lain yang akan menciptakan berbagai macam kalimat bermakna sehingga orang yang diajak berkomunikasi tersebut akan mudah memahaminya. Penggunaan bahasa menurut kurikulum tidak dapat dipisahkan oleh beberapa prinsip antara lain: 1) Adanya hubungan antara empat aspek bahasa yaitu menyimak, berbicara, membaca dan menulis, 2) Literatur adalah hal yang sangat penting dalam kegiatan bahasa yang memberikan kontribusi besar pada empat aspek bahasa, 3) Menggunakan dan mempelajari bahasa secara ilmiah dapat dilakukan seiring dengan mempelajari ilmu bidang lainnya. Hal tersebut menunjukan bahwa pembelajaran bahasa tidak hanya berbentuk teori saja tetapi harus ada praktek dengan menggunakan kreatifitas dan inovasi yang dibuat sehingga para siswa dapat menyerap dan mengimplementasikannya di kehidupan masyarakat.

Kebanyakan dareah-daerah terpencil masih mengalami kesulitan dalam melakukan pembelajaran bahasa, karena bahasa sehari-hari yang dipergunakan adalah bahasa daerah. Salah satu daerah tersebut adalah di daerah Katingan Hulu provinsi Kalimantan Tengah, kebanyakan masyarakat secara umum dan para siswa secara khusus disekolah menggunakan bahasa daerah dayak untuk berkomunikasi dan masih sedikit yang paham dan mengerti dalam menggunakan bahasa indonesia maupun bahasa inggris. SMA Negeri 1 Katingan Hulu Kabupaten Katingan Provinsi Kalimantan Tengah merupakan sekolah yang memiliki tujuan dalam peningkatan dan pembinaan dalam menumbuhkembangkan mutu seluruh 
potensi siswa yang ada termasuk sikap, kemampuan, dan keterampilan menuju hidup mandiri. Selain itu SMAN 1 Katingan Hulu juga memiliki tujuan:

1. Membentuk insan yang bertakwa dan berbudi pekerti luhur serta taat terhadap norma-norma yang berlaku di masyarakat

2. Meningkatkan mutu akademik lulusan sehingga dapat diterima di perguruan-perguruan tinggi favorit

3. Meningkatkan derajat kesehatan dan prestasi siswa sehingga mampu berprestasi semaksimal mungkin dalam kegiatan olahraga

4. Membentuk siswa menjadi manusia yang cinta seni, kreatif dan mampu mengekspresikan perasaannya lewat teater, vokal dan keterampilan lain

5. Meningkatkan pengetahuan, keterampilan dan kemampuan siswa dalam hidup mandiri sehingga mampu mengatasi tantangan hidup yang semakin keras di masyarakat

6. Membuka cakrawala pandangan siswa untuk selalu cinta pada lingkungan dan mampu melakukan penelitian serta menuangkan dalam bentuk laporan ilmiah.

SMAN 1 Katingan Hulu juga memiliki beberapa fasilitas yang sudah memadai dan letak sekolah ini sangatlah strategi karena terletak dipinggir jalan. Oleh karena itu penelitian ini dilakukan disalah satu sekolah yang ada di daerah Katingan Hulu yaitu SMAN-1 Katingan Hulu Kabupaten Katingan untuk mencari cara apa saja yang dilakukan dan bagaimana peranan teknologi dalam meningkatkan mutu pembelajaran bahasa yaitu bahasa inggris dan bahasa indonesia di sekolah tersebut.

\section{METODE}

Jenis penelitian ini menggunakan metode kualitatif dan kuantitatif (mixing). Metode kualitatif digunakan untuk meneliti pada kondisi objektif yang alamiah (lawannya adalah metode eksperimen). Selain itu metode ini instrumennnya adalah orang yaitu peneliti itu sendiri dan hasil dari penelitian kualitatif yaitu lebih bersifat makna dari data yang diperoleh (Suryana, 2010). Data yang diperoleh dari penelitian dengan metode kualitatif adalah berasal dari hasil interview dan obervasi. Interview digunakan untuk menggali informasi yang ada tentang penerapan teknologi dalam pembelajaran bahasa (bahasa inggris maupun bahasa indonesia) dan tingkat kemampuan guru dalam menggunakan media tersebut, dan untuk observasi digunakan untuk mengamati langsung penggunaan teknologi dalam pembelajaran bahasa oleh guru didalam kelas. Interview dilakukan terhadap 5 orang guru yang ada di SMAN 1 Katingan Hulu Kabupaten Katingan yaitu Kepala Sekolah, Wakil Kepala Sekolah Bagian Kurikulum, Guru Bahasa Indonesia, Guru Bahasa Inggris dan Guru Agama Hindu dimana proses interview menjadi data pendukung untuk data kuantitatif.

Metode kuantitatif dinamakan metode tradisional karena sudah lama dipergunakan dan biasanya variabel hasil dari metode ini dapat diperoleh dalam bentuk angka-angka dan menggunakan statistik (Suryana, 2010). Sedangkan data yang diperoleh dari metode kuantitatif adalah berasal dari data kuesioner yang berasal dari beberapa pertanyaan yang diberikan kepada para siswa untuk menunjukan kemampuan mereka dalam penggunaan teknologi informasi terhadap pembelajaran bahasa baik itu pembelajaran bahasa indonesia maupun pembelajaran bahasa inggris di SMAN-1 Katingan Hulu. Kuesioner diberikan kepada para siswa siswi kelas $\mathrm{X}$ yang beragama Hindu. Teknik analisis data pada penelitian ini dilakukan dengan beberapa langkah yaitu :

1. Penabulasian yaitu penyusunan data kedalam sebuah tabel dimana memiliki tujuan agar data dapat dengan mudah disusun maupun dijumlah 
2. Penginputan data dengan memasukan data yang ada diangket ke aplikasi dalam hal ini yaitu menggunakan microsoft Excel

3. Pengkodean data, dimana data disetiap pertanyaan akan diberikan kode agar dapat dengan mudah dilakukan perhitungan

4. Pengelompokan data yang ada diangket akan dikelompokkan berdasarkan kode yang telah ditetapkan

5. Pengkalkulasian dengan menggunakan skala likert.

Metode pengukuran dengan menggunakan skala likert merupakan salah satu metode untuk melihat perilaku seseorang terhadap suatu kejadian dan peristiwa tertentu. Alat ukur yang biasanya digunakan adalah dalam bentuk butir-butir pertanyaan yang dianggap sebagai indikator dalam menentukan sikap dan perilaku. (Budiaji, 2013) terdapat beberapa penelitian yang menganggap bahwa skala likert adalah skala interval sebagai contoh dalam mengukur kebiasaan memakan makanan sehat dimana analisis dari jawaban pertanyaan dapat menggunakan skor total dari jumlah jawaban disetiap pertanyaan. Skala likert merupakan pengukuran terhadap beberapa butir pertanyaan yang kemudian akan membentuk skor/nilai sehingga memperlihatkan tingkat persetujuan dari responden terhadap pertanyaan yang diajukan. Adapun beberapa langkah perhitungan dengan menggunakan skala likert (Much, Subroto, Farisa, \& Haviana, 2016) yaitu,

1. Tentukan terlebih dahulu skala jawaban

2. Menghitung nilai skor kriterium

Skor kriterium $=$ nilai skala jawaban $x$ jumlah responden

3. Setelah diperoleh skor kriterium masingmasing skala, tentukan nilai rating skala dimana akan ditentukan batas bawah terendah

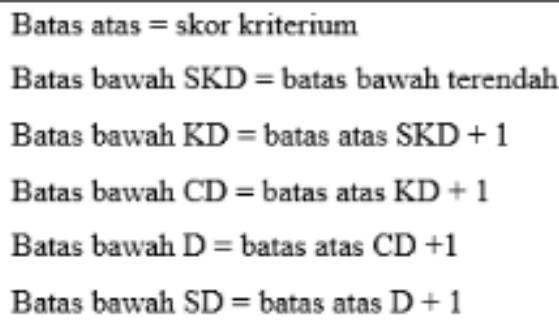

4. Mencari hasil dari masing-masing pertanyaan untuk masing-masing kriteria jawaban

Hasil = frekuensi kemunculan jawaban $x$ nilai skala

5. Setelah diperoleh hasil dari masingmasing skala jawaban, maka seluruh hasil akan dijumlahkan

Skor Akhir =

hasilSD + hasilD + hasil KD + hasilCD nilai skala terbesar $x 100$

Nilai skor akhir akan digunakan untuk menentukan daerah jawaban satu pertanyaan, dimana skor akhir dimasukan dan dicocokan dengan data rating skala yang telah diperoleh berdasarkan skor kriterium

6. Penginterprestasian dan penyimpulan hasil akhir dari masing-masing pertanyaan akan dijumlahkan untuk dirata-ratakan sehingga dapat dilakukan analisa data dan pengambilan kesimpulan dari hasil penyebaran angket.

Lokasi penelitian dilakukan di kabupaten Katingan yaitu di SMAN-1 Katingan Hulu, dimana lokasi ini dipilih untuk mendapatkan informasi seputar peranan penggunaan teknologi dalam pembelajaran bahasa, dan selain itu di SMAN-1 Katingan Hulu siswa yang beragama Hindu sangat banyak sehingga dapat memberikan kontribusi kepada lembaga pendidikan tinggi Hindu dalam hal ini IAHN Tampung Penyang Palangka Raya.

\section{HASIL DAN PEMBAHASAN}

\subsection{Hasil}

SMAN-1 Katingan Hulu memiliki tujuan, salah satunya adalah meningkatkan 
mutu akademik lulusan sehingga dapat diterima di perguruan tinggi favorit. Peningkatan mutu merupakan usaha yang dilakukan baik itu oleh pemerintah secara umum maupun sekolah-sekolah secara khususnya agar pendidikan yang berkualitas dapat diimplementasikan. (Fadhli, 2017) mengatakan upaya peningkatan mutu pendidikan merupakan hal yang terus menerus menjadi bahan kajian dalam mengelola pendidikan, dimana hal ini akan menjadi usaha yang harus diupayakan sehingga harapannya dapat menghasilkan kualitas pendidikan yang siap bersaing. Untuk mengetahui implikasi dari penelitian yang dilakukan di SMAN-1 Katingan Hulu dalam meningkatkan mutu pendidikan pembelajaran bahasa, maka penelitian ini menggunakan cara untuk mempermudah dalam penjabaran data kuantitatif yang diperoleh dari sebaran kuesioner dengan memberikan kode berdasarkan masingmasing pertanyaan. Pengkodeannya seperti dibawah ini :

\begin{tabular}{|l|l|l|}
\hline No. & Pertanyaan & Kode \\
\hline 1. & $\begin{array}{l}\text { Apakah saudara selalu } \\
\text { memperhatikan Guru } \\
\text { mengajar didepan kelas }\end{array}$ & A1 \\
\hline 2. & $\begin{array}{l}\text { Apakah dalam } \\
\text { penyampaian materi } \\
\text { dikelas sangat } \\
\text { menyenangkan ? }\end{array}$ & A2 \\
\hline 3. & $\begin{array}{l}\text { Apakah Guru } \\
\text { menggunakan media } \\
\text { teknologi informasi pada } \\
\text { pembelajaran Bahasa }\end{array}$ & B1 \\
\hline 4. & $\begin{array}{l}\text { Apakah di sekolah terdapat } \\
\text { media teknologi informasi } \\
\text { untuk membantu mencari } \\
\text { informasi materi pelajaran } \\
\text { bahasa? }\end{array}$ & B2 \\
\hline 5. & $\begin{array}{l}\text { Apakah Guru pernah } \\
\text { menggunakan video visual } \\
\text { untuk menerangkan } \\
\text { pembelajaran bahasa di } \\
\text { kelas ? }\end{array}$ & B3 \\
\hline dst & & \\
\hline
\end{tabular}

Setelah semua pertanyaan diberikan kode kemudian menentukan kriteria penilaian dari jawaban yang diisi oleh para responden dengan penentuan sebagai berikut

\begin{tabular}{|l|c|}
\hline \multicolumn{1}{|c|}{ Skala Jawaban } & Nilai Skala \\
\hline Selalu Sering & 5 \\
\hline Sering & 4 \\
\hline Kadang-Kadang & 3 \\
\hline Jarang & 2 \\
\hline Tidak Pernah & 1 \\
\hline
\end{tabular}

Semua jawaban yang dibuat oleh para responden akan diinput sesuai dengan nilai skala yang dibuat. Setelah dijabarkan maka akan dibuat rating skala dengan hasil seperti dibawah ini :

\begin{tabular}{|c|c|c|c|c|l|}
\hline Skala & $\begin{array}{c}\text { Jml } \\
\text { respon } \\
\text { den }\end{array}$ & $\begin{array}{c}\text { Nilai } \\
\text { skala }\end{array}$ & $\begin{array}{c}\text { Skor } \\
\text { Kriteri } \\
\text { um }\end{array}$ & $\begin{array}{c}\text { Nilai } \\
\text { Jawaban }\end{array}$ & $\begin{array}{l}\text { Persentase } \\
\text { jawaban }\end{array}$ \\
\hline SS & 38 & 5 & 190 & $153-190$ & $\begin{array}{l}80 \%- \\
100 \%\end{array}$ \\
\hline S & 38 & 4 & 152 & $115-152$ & $\begin{array}{l}60 \%- \\
79,99 \%\end{array}$ \\
\hline KK & 38 & 3 & 114 & $77-114$ & $\begin{array}{l}40 \%- \\
59,99 \%\end{array}$ \\
\hline J & 38 & 2 & 76 & $39-76$ & $\begin{array}{l}20 \%- \\
39,99 \%\end{array}$ \\
\hline TP & 38 & 1 & 38 & $0-38$ & $0-19,9 \%$ \\
\hline
\end{tabular}

Tabel 3 menunjukan hasil skor kriterium yang diperoleh dimana jumlah respondennya adalah sebanyak 38 orang. Berdasarkan rumus perhitungan maka skala "Sangat Sering" memperoleh skor 190, skala "Sering" memperoleh skor 152, skala "Kadang-kadang" memperoleh skor 114, skala "Jarang" memperoleh skor 76 dan skala "Tidak Pernah" memperoleh skor 38. Data kriterium juga menampilkan rating scale yaitu untuk jawaban "Sangat Sering" nilainya berkisaran antara 153-190, skala "Sering" nilainya berkisaran antara 115-152, skala "Kadang-kadang" nilainya berkisaran antara 77-114, skala "Jarang" nilainya berkisaran antara 39-76 dan skala "Tidak Pernah" nilainya berkisaran antara 0-38.

Masing-masing pertanyaan yang disampaikan pada angket maka didapat frekuensi skala jawaban yang diberikan oleh para responden yang dapat dilihat pada tabel 
berikut ini, dengan menampilkan sampel dari pertanyaan yang diajukan :

a. Motivasi belajar siswa di kelas

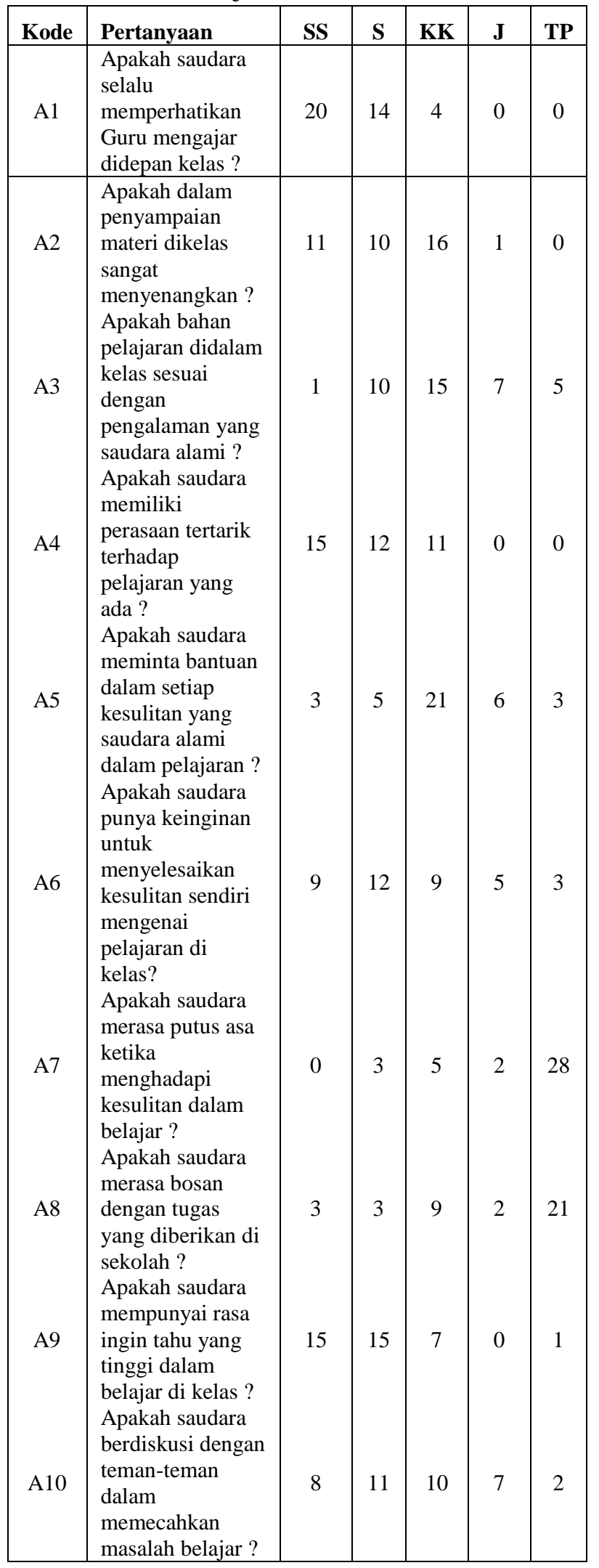

b. Peranan Teknologi dalam pembelajaran bahasa

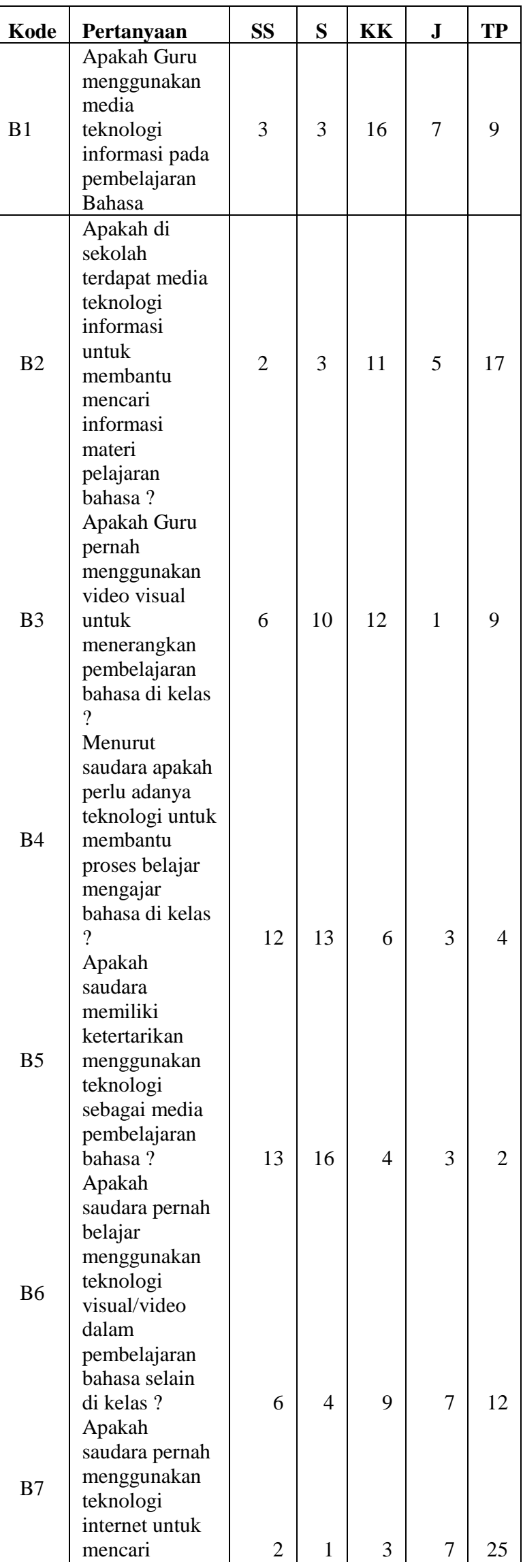




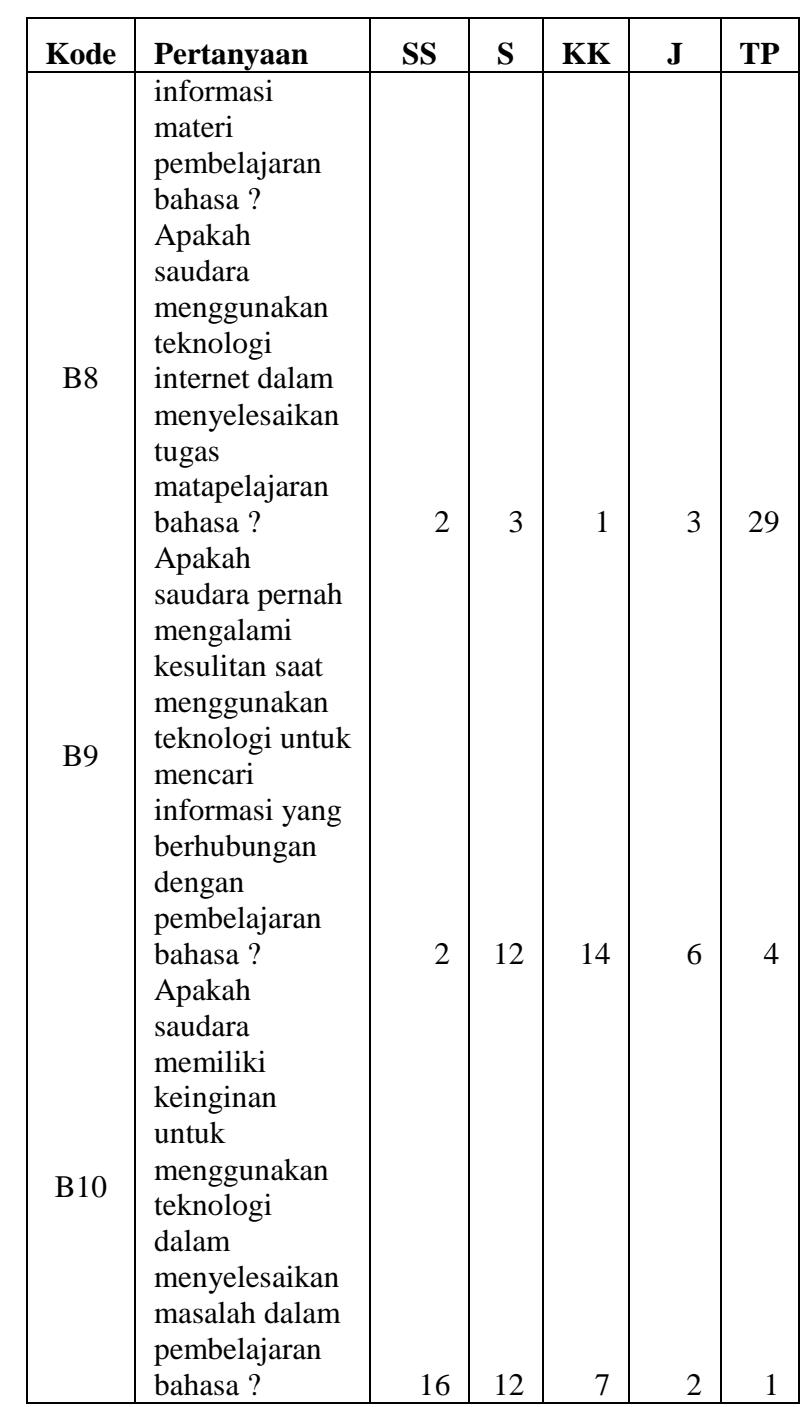

Angket dan kuesioner yang disebarkan terdapat dua jenis pertanyaan yaitu tentang motivasi belajar siswa di kelas dan tentang peranan teknologi dalam pembelajaran bahasa. Pada tabel 4 menunjukan bahwa untuk pertanyaan pertama frekuensi pada skala jawaban "SS" yaitu 20, frekuensi skala jawaban "S" adalah 14, frekuensi skala untuk jawab "KK" adalah 4, frekuensi skala jawaban "J" adalah 0 dan frekuensi skala jawaban "TP" adalah 0. Data frekuensi jawaban responden tersebut akan didapat skala rata-rata jawabannya seperti pada tabel dibawah ini :

\begin{tabular}{|l|l|l|}
\hline No & Pertanyaan & Persentase \\
\hline 1 & $\begin{array}{l}\text { Motivasi belajar siswa } \\
\text { dikelas }\end{array}$ & $65,5 \%$ \\
\hline 2 & $\begin{array}{l}\text { Peranan teknologi } \\
\text { dalam pembelajaran } \\
\text { bahasa }\end{array}$ & $56,3 \%$ \\
\hline
\end{tabular}

Berdasarkan hasil persentase rata-rata pada Tabel 6, didapat bahwa motivasi belajar siswa dikelas rata-rata memiliki $65,5 \%$ artinya para siswa di SMAN-1 Katingan Hulu rata-rata sering memperhatikan guru dikelas dan selain itu para siswa juga memiliki keinginan untuk memecahkan masalah dan berdiskusi kepada para siswa lain untuk proses pembelajaran. Para siswa juga lebih merasa tertarik dengan pelajaran yanga ada dikelas dikarena penyampaian materi yang disampaikan oleh para guru sangat menyenangkan sehingga dapat disimpulkan bahwa para siswa memiliki motivasi belajar yang tinggi.

Sedangkan dalam peranan teknologi pembelajaran bahasa memiliki nilai rata-rata $56,3 \%$ artinya para siswa maupun para tenaga pendidik yaitu guru kadang-kadang menggunakan teknologi dalam proses pembelajaran bahasa. Padahal dari saran yang diperoleh dari hasil kuesioner para siswa menganggap bahwa perlu adanya teknologi dalam membantu proses belajar mengajar bahasa dikelas, selain itu siswa juga sering mengalami kesulitan dalam mencari bahan yang digunakan untuk menyelesaikan tugas pada matapelajaran bahasa yang dikarenakan belum adanya teknologi internet di daerah Katingan Hulu Kabupaten Katingan.

Selain diperolehnya data kuantitatif dengan menggunakan kuesioner/angket, penelitian ini juga melakukan teknik wawancara untuk mendukung analisa data. Wawancara dilakukan kepada pihak pengelola sekolah yaitu kepala sekolah, guru bahasa inggris, guru bahasa indonesia, dan guru agama. Hasil wawancara dengan Kepala Sekolah SMAN-1 Katingan Hulu menyatakan bahwa di sekolah sudah menggunakan beberapa perangkat media pembelajaran misalnya guru sudah menggunakan proyektor dalam penyampaian materi dan tidak selalu menggunakan metode ceramah, tetapi ada kesulitan yang 
dialami oleh guru-guru di SMAN-1 Katingan Hulu yaitu dalam pengembangan bahan ajar untuk menghasilkan pembelajaran yang kreatif dan inovatif kepada para siswa mengingat SMAN-1 Katingan Hulu sudah menerapkan kurikulum 2013.

Sedangkan Guru Bahasa Inggris dan Bahasa Indonesia SMAN-1 Katingan Hulu juga mengatakan bahwa dalam pembelajaran sudah menggunakan media elektronik seperti penggunaan LCD proyektor serta penggunaan dengan microsoft power point. Selain menggunakan media tersebut, para guru juga sudah menggunakan buku paket elektronik yang ditampilkan pada media android dan smartphone Kesulitan lain yang dialami oleh Guru Bahasa Indonesia dan guru Bahasa Inggris adalah penggunaan bahasa pengantar yaitu bahasa Indonesia dalam proses pembelajaran dikarenakan sebagian besar siswa yang ada di SMAN-1 Katingan Hulu sulit memahami dalam penggunaan bahasa Indonesia dikarenakan para siswa lebih menguasai bahasa daerah setempat. Apalagi pembelajaran bahasa Inggris harus memerlukan alat bantu atau media misalnya dalam pelafalan serta pengucapan bahasa inggris yang merupakan bahasa asing.

\subsection{Pembahasan}

Pendidikan menjadi dasar bagi masyarakat untuk siap bersaing di segala bidang dalam meningkatkan kualitas hidup masyarakat agar lebih sejahtera. Perlu adanya mutu suatu pendidikan di suatu negara sehingga menghasilkan masyarakat yang siap bersaing baik ditingkat nasional maupun internasional. Peningkatan mutu suatu pendidikan tidak bisa lepas dari berbagai inovasi dan kreatifitas pengembangan baik itu dalam hal penggunaan bahan ajar serta proses pembelajaran yang dilakukan. Seiring dengan berkembanganya jaman, tidak bisa lepas dari perkembangan teknologi yang menjadi kebutuhan untuk membantu dalam kehidupan masyarakat.

Salah satu terobosan yang sudah dilakukan pemerintah untuk meningkatkan mutu pendidikan saat ini adalah dengan menerapkan kurikulum 2013 baik itu di tingkat SMA, SMP maupung SD. (Jusnita \& Ismail, 2018) mengatakan bahwa kurikulum 2013 lebih kepada upaya penyederhanaan dengan tematik integratif dimana mendorong para peserta didik agar lebih mampu melakukan pengamatan, bertanya, serta berkomunikasi terhadap apa yang telah didapat. Inilah yang membuat para peserta didik harus bisa kreatif dan inovatif dalam mengimplementasikan materi yang telah diterima. (Katuuk, 2014) terdapat tiga kegiatan utama dalam rencana implementasi pelaksanaan kurikulum 2013 antara lain penyediaan buku atau bahan ajar, penyediaan sumber daya manusia dalam hal ini tenaga pengajar dan kegiatan evaluasi serta monitoring. Salah satu rencana kegiatan tersebut menjadikan guru harus mampu mengembangkan dalam melakukan strategi pembelajaran dimana dapat menggunakan beberapa pendekatan model dan media pembelajaran yang inovatif dan kreatif sesuai dengan perkembangan saat ini. Kurikulum 2013 menggunakan beberapa pendekatan pembelajaran yang dilakukan antara lain :

1. Bahan ajar yang dipelajari lebih bersifat pada fenomena dan peristiwa yang terjadi dimana dapat dijelaskan berdasarkan fakta yang ada.

2. Penjelasan dari guru dan respon siswa merupakan interaksi edukatif yang berasal dari inspirasi dan penalaran yang diperoleh

3. Mendorong siswa untuk selalu berpikir secara logis, menganalisa, mengidentifikasikan suatu masalah, memahami dan serta memecahkan suatu masalah sehingga dapat mengimplementasikan materi yang disampaikan 
4. Menginspirasi siswa untuk bisa menerapkan dan mengembangkan pola pikir yang rasional dan objektif dalam menerima materi yang disampaikan

5. Teori, konsep dan fakta yang terjadi sebagai contoh dalam pembelajaran dapat dipertanggungjawabkan

6. Pembelajarannya akan menjadi lebih menarik walaupun disampaikan secara sederhana jelas, (Sinambela, 2013).

Adanya penerapan kurikulum 2013 menuntut sistem pembelajaran yang kreatif dan inovatif dimana disesuai dengan perkembangan jaman, sehingga diperlukannya suatu media pembelajaran yang dapat membantu untuk transfer knowladge antara tenaga pendidik dengan siswa. Salah satu media yang dapat dipergunakan adalah media teknologi pendidikan, secara langsung media ini dapat meningkatkan mutu pendidikan dalam mendukung program pelaksanaan kurikulum 2013 yang telah diterapkan.. Dari hasil penelitian serta wawancara yang di lakukan di SMAN-1 Katingan Hulu, para tenaga pendidik/guru juga sudah menggunakan teknologi informasi dalam mendukung penerapan kurikulum 2013 misalnya di SMAN-1 Katingan Hulu guru bahasa indonesia dan guru bahasa inggris sudah menggunakan video pembelajaran dan buku elektronik sehingga proses belajar mengajar dikelas menjadi lebih dinamis dan kreatif walaupun intensitas penggunaannya tidak sering digunakan. Pengaruh dari penggunaan media teknologi pendidikan yang digunakan dalam pembelajaran bahasa di SMAN-1 Katingan Hulu adalah dapat meningkatkan motivasi belajar siswa di kelas yang mana hasil tersebut dapat dilihat dari hasil penyebaran angket ke siswa. Hal inilah yang menjadi salah satu tujuan yang dimiliki oleh lulusan SMAN-1 Katingan Hulu yang mana nantinya lulusan atau output yang ada bisa bersaing ditingkat nasional maupun internasional.
Wawancara dengan pihak sekolah dalam hal ini kepala sekolah dan para guru di SMAN-1 Katingan Hulu ditemukan beberapa informasi tentang kendala yang dihadapi dalam penggunaan teknologi informasi untuk meningkatkan mutu pendidikan pembelajaran bahasa :

1. Penguasaan penggunaan teknologi informasi pada tenaga pendidik masih kurang, padahal media ini diperlukan untuk mendukung adanya proses pembelajaran yang kreatif dan inovatif.

2. Belum adanya teknologi internet didaerah Katingan Hulu, dimana memerlukan adanya pengembangan bahan ajar disesuaikan dengan fenomena dan fakta yang sedang berkembang dalam penerapan kurikulum 2013

3. Para siswa sebagian besar belum menguasai penggunaan teknologi informasi dalam hal ini buku elektronik yang telah disediakan di perpustakaan sehingga perlu adanya peran guru dalam mebimbing penggunaan media tersebut.

SMAN-1 Katingan Hulu harus memiliki beberapa strategi dalam menyelesaikan kendala yang dihadapi sehingga visi dan misi yang telah dibuat dapat terwujud. Menurut (Moh. Saifulloh, 2012) jika sebuah institusi atau sekolah hendak meningkatkan mutu pendidikan terdapat beberapa faktor yang harus dilibatkan antara lain

1. Kepala sekolah, haruslah dapat memahami visi dan misi yang ada sehingga nantinya mampu menyalurkan maksud dari visi tersebut ke stackholder yang ada di sekolah

2. Terlibatnya guru secara maksimal kepada para siswa dengan meningkatkan kompetensi dan profesi guru melalui pelatihan, lokakarya maupun workshop yang kemudian dapat diterapkan di sekolah

3. Meningkatkan kreatifitas siswa melalui beberapa kegiatan yang berhubungan dengan pengembangan bahan ajar sesuai 
kurikulum yang digunakan sehingga nantinya siswa dapat memiliki kreatifitas dan inovasi dalam proses belajar mengajar

4. Kurikulum yang digunakan haruslah dinamis dinama dapat menyesuaikan perkembangan jaman yang nanti dapat melaksanakan sesuai dengan tujuan yang diharapkan

5. Jaringan kerjasama dimana diharapkan nantinya kerjasama tidak hanya antara sekolah dengan masyarakat saja, tetapi kerjasama dengan beberapa perusahaan dan pemerintahan sehingga dapat melihat kebutuhan lulusan yang diperlukan dalam dunia kerja.

Penjabaran diatas menunjukan bahwa peranan pimpinan di SMAN-1 Katingan Hulu dalam meningkatkan mutu pendidikan adalah mengembangkan dan menerapkan tujuan serta visi dan misi sekolah yang jelas untuk mencapai sasaran yang diharapkan. Visi yang ada di SMAN-1 Katingan Hulu adalah melahirkan generasi yang unggul, beriman dan bertaqwa, cerdas, terampil, kreatif dan berbudi pekerti luhur. Sedangan misi yang ada di SMAN-1 Katingan Hulu adalah berkualitas dan dapat melanjutkan pendidikan ke perguruan tinggi favorit; beriman dan bertaqwa kepada Tuhan Yang Maha Esa; mengenali potensi diri dan dapat hidup mandiri. SMAN-1 Katingan Hulu lebih mengutamakan untuk menghasilkan lulusan yang nantinya siap bersaing dalam mendapatkan pendidikan yang lebih tinggi. Hal ini dapat dilihat dari upaya pihak sekolah dalam menyediakan beberapa fasilitas yang ada di SMAN-1 Katingan Hulu antara lain adanya perpustakaan yang sudah memiliki buku digital, laboratorium bahasa, laboratorium IPA serta laboratorium komputer. SMAN-1 Katingan Hulu telah menyalurkan maksud visi dan misi yang ada dengan menerapkan kurikulum yang telah digunakan oleh pemerintah yang secara langsung akan meningkatkan kreatifitas dan inovasi dalam proses belajar mengajar baik guru dan siswa. Dalam menangani masalah penggunaan teknologi informasi sebagai media pendukung dalam meningkatkan mutu pendidikan, guru-guru serta siswa yang ada di SMAN-1 Katingan Hulu perlu dilakukannya kerja sama dengan pemerintahan daerah maupun perguruan tinggi yang ada di Kalimantan Tengah untuk melakukan kegiatan pelatihan penggunaan teknologi pembelajaran yang inovatif dan kreatif.

Selain itu untuk pengadaan media teknologi internet, diharapkan adanya kerjasama antara pihak sekolah dengan pihak jasa ISP (Internet Service Provider) yang didukung oleh pemerintahan daerah sehingga nantinya teknologi tersebut dapat digunakan oleh para siswa maupun para guru sebagai pendukung dalam proses belajar mengajar. Bentuk lain yang dapat ditunjukan di SMAN-1 Katingan Hulu adalah dengan penerapan kurikulum 2013 dan kedepannya penguatan penerapan kurikulum tersebut juga dapat dilakukan dengan pelatihan atau workshop dalam pengembangan bahan ajar, pengembangan media belajar, evaluasi siswa serta sistem penilaian dikelas yang merangsang kreatifitas dan inovasi siswa.

\section{KESIMPULAN}

Berdasarkan hasil analisa dan pembahasan diatas maka dapat ditarik kesimpulan bahwa pengembangan bahan ajar yang menarik dan menyenangkan dapat mengajak para siswa untuk selalu berpikir kreatif sehingga para siswa lebih bersemangat dalam meningkuti proses belajar mengajar dikelas. Hal tersebut telah diterapkan di SMAN-1 Katingan Hulu dimana teknologi yang telah diterapkan walaupun intensitas penggunaannya tidak sering digunakan dapat memotivasi siswa untuk melakukan proses belajar baik dikelas maupun diluar kelas. Para siswa di SMAN-1 Katingan Hulu juga merasakan bahwa peranan teknologi sangat penting untuk mencari bahan pembelajaran bagi para siswa. 


\section{DAFTAR PUSTAKA}

Budiaji, W. (2013). Skala Pengukuran dan Jumlah Respon Skala Likert. Jurnal Ilmu Pertanian Dan Perikanan, 2(2), 127-133. Retrieved from https://osf.io/preprints/inarxiv/k7bgy/

Fadhli, M. (2017). Manajemen Peningkatan Mutu Pendidikan. Jurnal Studi Manajemen Pendidikan, 1(2). Retrieved from http://dx.doi.org/10.29240/jsmp.v1i2.2 95

Fridani, Lara; Dhieni, N. (2014). Hakikat Perkembangan Bahasa Anak. In Metode pengembangan bahasa (pp. 128). Retrieved from http://www.pustaka.ut.ac.id/lib/wpcontent/uploads/pdfmk/PAUD4106M1.pdf

Jusnita, N., \& Ismail, A. (2018). Implementasi Kurikulum 2013 Dalam Pembelajaran Bahasa Inggris di SMP Kota Ternater. Jurnal Pendidikan, 16(1), 1-10. Retrieved from http://ejournal.unkhair.ac.id/index.php /edu/article/view/616

Katuuk, D. A. (2014). Manajemen Implementasi Kurikulum: Strategi Penguatan Implementasi Kurikulum 2013. Jurnal Cakrawala Pendidikan, 33(1), 13-26.

Kwartolo, Y. (2010). Teknologi Informasi dan Komunikasi dalam proses Pembelajaran. Jurnal Pendidikan Penabur, 14(9), 15-43. Retrieved from

http://bpkpenabur.or.id/dokuploads/20 15/10/jurnal-No14-Thn9-Juni2010.pdf

Marzal, J. (2014). Desain Media Pembelajaran Bahasa Inggris Untuk Siswa TunaRungu Berbantuan Teknologi Informasi dan Komunikasi. Jurnal Tekno-Pedagogi, 4(2), 32-44. Retrieved from https://onlinejournal.unja.ac.id/pedagogi/article/vie w/2291
Moh. Saifulloh. (2012). Strategi peningkatan mutu pendidikan di sekolah. Jurnal Sosial Humaniora, 5(2), 206-218.

Much, I., Subroto, I., Farisa, S., \& Haviana, C. (2016). Sistem Informasi Angket Pengukuran Skala Kebutuhan Materi Pembelajaran Tambahan Sebagai Pendukung Pengambilan Keputusan Di Sekolah Menengah Atas Menggunakan Skala Likert. Jurnal Transistor Elektro Dan Informatika, 1(2), 1-12. https://doi.org/http://dx.doi.org/10.306 59/ei.1.1.1-12

Muhson, A. (2010). Pengembangan Media Pembelajaran Berbasis Teknologi Informasi. Jurnal Pendidikan Akuntansi Indonesia, VIII(2), 1-10. https://doi.org/https://doi.org/10.21831 /jpai.v8i2.949

Rogers, E. M. (1986). Communicarion Technology The New Media in Society. Michigan:Free Press.

Sapto, H. (2009). Efektivitas Pemanfaatan Media Audio-Visual Sebagai Alternatif Optimalisasi Model Pembelajaran. Jurnal Edukasi @Elektro, 5(1), 1-10.

Sinambela, P. N. J. M. (2013). Kurikulum 2013 dan Implementasinya dalam pebelajaran. Jurnal Generasi Kampus, 6(3), 17-29. Retrieved from https://jurnal.unimed.ac.id/2012/index. $\mathrm{php} / \mathrm{gk} /$ article/view/7085

Sudarsana, I. K. (2017). Peningkatan Mutu Pendidikan Agama Hindu Melalui Efektivitas Pola Interaksi Dalam Pembelajaran Di Sekolah. Prosiding Semaya 2, (Semaya II), 134-142.

Suryana. (2010). Metodologi penelitian.

Triyanto, Eko; Anitah, Sri; Suryani, N. (2013). Peran Kepemimpinan Kepala Sekolah Dalam Pemanfaatan Media Pembelajaran Sebagai Upaya Peningkatan Kualitas Proses Pembelajaran. Jurnal Teknologi Pendidikan, 1(2), 226-238. Retrieved from https://eprints.uns.ac.id/1754/ 